\title{
Conditions for the successful implementation of teacher educator design teams for ICT integration: A Delphi study
}

\author{
Heleen Becuwe \\ Ghent University, Belgium \\ Natalie Pareja Roblin \\ Ghent University, Belgium; University of Pittsburgh, USA
}

\section{Jo Tondeur}

Ghent University, Belgium; Vrije Universiteit Brussel, Belgium

Jeroen Thys and Els Castelein

University Colleges Leuven-Limburg, Belgium

\section{Joke Voogt}

University of Amsterdam, The Netherlands

\begin{abstract}
Teacher educators often struggle to model effective integration of technology. Several studies suggest that the involvement of teacher educators in collaborative design is effective in developing the competences necessary for integrating information and communication technology (ICT) in teaching. In a teacher educator design team (TeDT), two or more teacher educators (re-)design curriculum materials together. For the successful implementation of TeDTs, conditions at both team and institutional levels have to be taken into account. However, there is little consensus among stakeholders about which of these conditions are of highest priority. Most studies present priority or critical conditions from the viewpoint of just one group (e.g., school leaders). A Delphi study was set up aiming at synthesising the knowledge and views of various stakeholders about the conditions for the successful implementation of TeDTs for ICT integration. Consensus about the importance of ten conditions was reached in the entire sample after three rounds. These conditions include a long-term vision, trust, ownership, time and supportive institutional policies.
\end{abstract}

\section{Introduction}

Information and communication technology (ICT) integration in teaching and learning processes is a key component of many educational reform agendas worldwide (e.g., Aesaert, Vanderlinde, Tondeur, \& Van Braak, 2013). A crucial factor for the successful integration of ICT in education is the preparation of future teachers (Banas \& York, 2014; Lee \& Lee, 2014; Peeraer \& Van Petegem, 2012). Yet, research shows a gap between how ICT is addressed in teacher education institutions and what is expected from future teachers (e.g., Kay, 2006; Tondeur, Pareja Roblin, van Braak, Fisser, \& Voogt, 2013). One of the reasons for this gap is that teacher educators are not always familiar enough with the integration of ICT in education (Goktas, Yildirim, \& Yildirim, 2009; Tondeur, van Braak, Siddiq, \& Scherer, 2016)). Teacher educators are expected to model effective ICT integration and provide future teachers with the necessary ICT entry qualifications. Professional development and support are therefore needed to prepare teacher educators for this task (Goktas et al., 2009).

Collaborative design (in teacher design teams) of technology-enhanced lessons has been shown to contribute to the development of competencies necessary to integrate technology in education (e.g., Agyei \& Voogt, 2012; Alayyar, Fisser, \& Voogt, 2012; Polly, 2011). A teacher design team (TDT) can be described as a group of two or more (student) teachers or teacher educators who (re-)design curriculum materials together (Handelzalts, 2009). TDTs can be an effective strategy for professionalisation, when taking into account a number of conditions both at the team and institutional levels. Although previous studies have identified various factors that determine the optimal functioning of TDTs (e.g., Handelzalts, 2009; Voogt et al., 2011), it is not yet clear whether and to what extent these factors are regarded as (equally) important by stakeholders (Voogt et al., 2015). In order to address this gap, the current study aimed at 
establishing consensus across multiple stakeholder groups on the most critical conditions for the successful implementation of TDTs for ICT integration.

\section{Background of the study}

\section{ICT integration in teacher education}

The competences needed for ICT integration are not only related to technology use, but also to pedagogical attitudes and content planning. These competences are all interrelated and cannot be seen as separate from each other. The technological pedagogical content knowledge (TPACK) model, developed by Mishra and Koehler (2006) to guide technology integration in teacher education, brings these different competences together. The core of the TPACK model consists of the integrated components knowledge of technology (TK), 'pedagogical knowledge (PK) and content knowledge (CK). ICT integration in education is facilitated when teachers understand how these three knowledge domains are interrelated and how they interact (Voogt, Fisser, Pareja Roblin, Tondeur \& van Braak, 2013).

Yet, the research literature reveals that the transition from TK to TPACK in teacher education programs is not that simple (e.g., Niess et al., 2009). For example, Tondeur et al., (2013) investigated how three different teacher education institutions prepared pre-service teachers for the integration of ICT. Their study revealed that in all three institutions teacher educators were not yet adequately equipped with TPACK. Individual courses or workshops to provide teacher educators with ICT skills have been shown to be insufficient (Wentworth, Graham, \& Monroe, 2009). Alternative approaches are therefore needed to support teacher educators' - and thereby future teachers' - TPACK development.

\section{Teacher (educator) design teams for ICT integration}

As briefly mentioned in the introduction, an increasingly used strategy to familiarise teachers with the various components of the TPACK model is to let them (re-)design their own courses in (teacher design) teams (e.g., Alayyar et al., 2012; Angeli \& Valanides, 2005; Polly, 2011). Mishra and Koehler (2006) call this pedagogical approach "learning technology by design" (p. 1020). It means that teacher educators reflect together on how educational technology can support the content and pedagogical aspects of their practice in order to attain TPACK. Next, they design technology-enhanced materials, experiment with them and, finally, reflect on the results. All these strategies are also identified in the inner circle of the synthesis of qualitative data (SQD) model to prepare pre-service teachers for technology use (Tondeur, van Braak et. al, 2012), which includes designing, collaborating and reflecting, and testing and assessing newly developed technology-enhanced curriculum materials.

For the successful implementation of TDTs, several conditions need to be taken into account. Table 1 presents an overview of the literature on conditions that play a role for the implementation of TDTs, both at the team and institutional levels (e.g., Handelzalts, 2009; Voogt et al., 2011). It is important to note that conditions at the institutional level influence conditions at the level of the team; for instance, a noninnovative institutional culture will affect the innovative character of the design task and the innovative approach of a TDT. 
Table 1

Conditions for the implementation of TDTs

\begin{tabular}{|c|c|c|c|}
\hline Level & Themes & Conditions & Authors \\
\hline \multirow[t]{5}{*}{ Team level } & Design task & $\begin{array}{l}\text { Innovativeness, } \\
\text { concreteness, complexity, } \\
\text { kind of task, size of task, } \\
\text { real-world use }\end{array}$ & $\begin{array}{l}\text { e.g., Frankenberger \& Auer, } \\
\text { 1997; Handelzalts, 2009; Svihla, } \\
\text { Reeve, Sagy, \& Kali, } 2015\end{array}$ \\
\hline & Team composition & $\begin{array}{l}\text { Size, composition, } \\
\text { expertise, design } \\
\text { experience, educational } \\
\text { vision and motivation, } \\
\text { communicative skills, } \\
\text { ownership, interactions } \\
\text { technological and content } \\
\text { knowledge (TPACK), } \\
\text { visions, atmosphere of trust } \\
\text { and partnership }\end{array}$ & $\begin{array}{l}\text { e.g., Cober, Tan, Slotta, So, \& } \\
\text { Könings, 2015; Handelzalts, } \\
\text { 2009; Hord, 1997; Paulus, 2000; } \\
\text { Somech \& Drach-Zavachy, } \\
\text { 2007; Stoll, Bolam, McMahon, } \\
\text { Wallace, \& Thomas, 2006; } \\
\text { Tondeur, Pareja Roblin, \& } \\
\text { Thys, 2012; Huizinga, } \\
\text { Handelzalts, Nieveen, \& Voogt, } \\
2013\end{array}$ \\
\hline & Collaboration & $\begin{array}{l}\text { Interdependence, } \\
\text { construction of teaching } \\
\text { materials, frequency, } \\
\text { formal/informal, good work } \\
\text { relations }\end{array}$ & $\begin{array}{l}\text { e.g., Becuwe, Tondeur, Pareja } \\
\text { Roblin, Thys, \& Castelein, } \\
\text { 2016; Handelzalts, 2009; Little, } \\
\text { 1990; Somech \& Drach- } \\
\text { Zavachy, 2007; Stoll et al., } 2006\end{array}$ \\
\hline & Team activities & $\begin{array}{l}\text { Structure, types of } \\
\text { activities, design models, } \\
\text { technology mapping }\end{array}$ & $\begin{array}{l}\text { e.g., Agyei, 2012; Angeli \& } \\
\text { Valanides, 2009; Culatta, 2013; } \\
\text { Ehrlenspiel, Giapoulis, \& } \\
\text { Günther, 1997; Handelzalts, } \\
\text { 2009; Tondeur, van Braack et } \\
\text { al., } 2012\end{array}$ \\
\hline & $\begin{array}{l}\text { The role of the } \\
\text { coach }\end{array}$ & $\begin{array}{l}\text { Flexibility, roles (e.g., } \\
\text { catalyst, coordinator, } \\
\text { moderator), just-in-time } \\
\text { support, action vs. } \\
\text { reflection, group member } \\
\text { vs. expert, requested vs. } \\
\text { provided support, face-to- } \\
\text { face vs. digital support }\end{array}$ & $\begin{array}{l}\text { e.g., Becuwe et al., 2016; } \\
\text { Huizinga et al., 2013; } \\
\text { McKenney, Kali, Markauskaite, } \\
\text { \& Voogt, 2015; Jenlink \& } \\
\text { Kinnucan-Welsch, 2001; } \\
\text { Petrone \& Orquist-Ahrens, } 2004\end{array}$ \\
\hline \multirow[t]{4}{*}{$\begin{array}{l}\text { Institutional } \\
\text { level }\end{array}$} & External support & $\begin{array}{l}\text { External funding, } \\
\text { collaboration with } \\
\text { universities or other } \\
\text { organisations }\end{array}$ & $\begin{array}{l}\text { e.g., Huizinga et al., 2013; } \\
\text { Voogt et al., } 2011\end{array}$ \\
\hline & $\begin{array}{l}\text { The role of the } \\
\text { institution }\end{array}$ & $\begin{array}{l}\text { School culture, support, } \\
\text { leadership involvement }\end{array}$ & $\begin{array}{l}\text { e.g., Handelzalts, 2009; Hipp, } \\
\text { Huffman, Pankake, \& Olivier, } \\
\text { 2008; McLaughlin \& Talbert, } \\
\text { 2001; Voogt et al., } 2011\end{array}$ \\
\hline & $\begin{array}{l}\text { Coordination } \\
\text { procedures }\end{array}$ & $\begin{array}{l}\text { Interaction with other } \\
\text { TDTs, interactions with the } \\
\text { institution }\end{array}$ & e.g., Handelzalts, 2009 \\
\hline & $\begin{array}{l}\text { Structural } \\
\text { conditions }\end{array}$ & Time, place, infrastructure & $\begin{array}{l}\text { e.g., Handelzalts, 2009; } \\
\text { Hargreaves, 2011; Hord, 1997; } \\
\text { Stoll et al., 2006; Voogt et al., } \\
2011\end{array}$ \\
\hline
\end{tabular}

\section{Conditions at the team level}

At team level we identified and clustered conditions significant to the effective implementation of TDTs in five themes: nature of the design task, team composition, shared goals, team (design) activities and the role of the coach. Features of the design task, such as designing for real-world use, were found to support teachers as designers of technology-enhanced learning (Svihla et al., 2015). The composition of the team 
(e.g., team size, participants' background and expertise) also has important implications for the success of a TDT. Large and heterogeneous teams may require extra support (Handelzalts, 2009). Research also suggests that participants need common goals to work towards (e.g., Stoll et al., 2006). In this respect, the study of Binkhorst, Handelzalts, Poortman, and van Joolingen (2015) revealed that defining a goal together had a positive effect on the outcomes of the TDT. Next to a shared agenda, an atmosphere of trust has also been found to be central when teachers act as participatory designers (Cober et al., 2015). Feelings of trust and acceptance help teachers to co-design.

Beyond the conditions mentioned above, the activities mediating team interactions also play an important role in the effective implementation of TDTs. Systematic approaches such as the use of design models can be helpful to structure collaborative design activities (e.g., Culatta, 2013; Ehrlenspiel et al., 1997). The study of Svihla et al. (2015) suggests that design principles aren't sufficient guidance on their own, and that concrete design tools are good scaffolds to support teachers’ design work.

Another theme emerging from the literature pertains to the role of a coach or internal facilitator in TDTs (e.g., Huizinga et al., 2013; Jenlink \& Kinnucan-Welsch, 2001). Teachers require support when designing a task (Huizinga et al., 2013), and additional issues (i.e., self-efficacy for ICT integration in education) bear consideration when designing technology-enhanced materials (McKenney et al., 2015). In the study by Becuwe, Tondeur, Pareja Roblin, Thys, and Castelein (2016), focus group conversations with participants of TDTs revealed three main roles a coach can take: providing logistic support, scaffolding the design process and monitoring the design process.

\section{Conditions at the institutional level}

At the institutional level, conditions clustered in four themes (i.e., external support, the role of the institution, coordination procedures and structural conditions) were derived from literature. Next to internal support given by a coach, a design team can also benefit from external support such as (content) advice from university experts (Voogt et al., 2011). Policy support also proves essential to enable collaboration: an innovation such as the implementation of a TDT needs to be acknowledged and supported by institutional policy (Voogt et al., 2011). Handelzalts (2009) also underscores the importance of the coordination between different TDTs on the one hand, and between TDTs and the rest of the institution on the other hand. However, the role of policy might vary depending on the specific context. For example, in the study of Binkhorst et al. (2015), both quantitative and qualitative data show that there is almost no relationship between the contextual characteristics (i.e., school's reform conditions, degree of involving teachers in school and school's conditions for supporting TDTs) and the outcomes of the TDTs. The authors note that possible explanations for this could be that teams consisted of participants from different schools, or that teachers in the Netherlands are relatively autonomous. Finally, a number of studies reveal that structural conditions such as time and budget play a fundamental role too (e.g., Handelzalts, 2009; Hargreaves, 2011; Hord, 1997; Voogt et al., 2011).

\section{Purpose of the study}

The study of teacher educators' professional development has long been neglected (e.g., Knight et al., 2014; Tack \& Vanderlinde, 2014), even though teacher educators are tasked with helping student teachers to acquire the necessary entry competences. Research suggests that collaborative design of technologyenhanced lessons in TDT can be an effective professional development strategy (e.g., Alayyar et al., 2012). In this paper, we use the term teacher educator design team (TeDT) to refer specifically to a TDT consisting of teacher educators.

The implementation of TeDTs can be successful once certain conditions are met (see Table 1). However, there seems to be little consensus across multiple stakeholders (e.g., participants of TDTs, coaches, coordinators of the teacher education program and researchers) about whether and to what extent these conditions are (equally) important. With the ultimate aim of developing a framework for the successful implementation of TeDTs for ICT integration, this study sought consensus about conditions that are regarded as crucial across multiple stakeholder groups. 


\section{Methodology}

\section{Delphi study}

To build consensus about the crucial conditions for the successful implementation of TeDTs for ICT integration, a Delphi study was set up. A Delphi study involves (1) consulting a mature field of experts (2) in an anonymous manner (3) in different rounds, (4) with feedback of the results and (5) the opportunity for participants to reconsider their position (Koster, 2003). The Delphi method was chosen because it is specifically directed towards generating consensus in a group of respondents (Hsu \& Sandford, 2007; Shaikh \& Khoja, 2014). Developing a framework may be another outcome of a Delphi study (Okoli \& Pawlowski, 2004). In the current study, the researchers strove for a consonant framework of the conditions necessary for the implementation of TeDTs for ICT integration that induce consensus.

For this Delphi study, both qualitative and quantitative methods were used. The Delphi study consisted of three rounds of data collection and analysis. These are discussed in depth in the Conduct of the Delphi study and analysis of the results section. The estimated time span of the iterative data collection rounds was eight months, starting with the first round in July 2014 and ending with the last round in February 2015.

\section{Selection of experts}

Expertise is considered to be the most important criterion for selecting a Delphi participant (Shaikh \& Khoja, 2014); that is, a participant in a Delphi study must be a proven expert in the field of the study. In order to bring multiple perspectives together, we purposely chose to synthesise the knowledge of all stakeholders involved in a professional development project about TeDTs in Flanders (the Dutch-speaking northern portion of Belgium). Four education institutions collaborated in this project (for more information about the project, please visit http://www.teacherdesignteams.be/). The central objective of the project was analysing, supporting and facilitating the methodology of TDTs as a professional development strategy for ICT integration. To this end each TeDT had to collaboratively design and develop digital curriculum materials that could be implemented in the teacher preparation programs. Each of the four participating institutions started a TeDT consisting of three to four teacher educators and one coach.

Thirty-six respondents distributed across four stakeholder groups participated in the study (Table 2). The first group included the 14 teacher educators who took part in the TeDTs. They all joined the first round but, because of changes in jobs or temporal leave, not all moved on to the second and third round. The four coaches, and the project coordinators who supported the coaches in a coaching trajectory, formed a second stakeholder group. Due to maternity leave one coach was unable to participate in the second round. The coordinators of the teacher education programs were included as a separate group as well. The last group of stakeholders consisted of researchers in the field of teacher professional development and/or ICT integration.

Table 2

Participants of the Delphi study

\begin{tabular}{lccc}
\hline Group & $\begin{array}{c}\boldsymbol{N} \text { (1st round in } \\
\text { June 2014) }\end{array}$ & $\begin{array}{c}\boldsymbol{N} \text { (2nd round in } \\
\text { October 2014) }\end{array}$ & $\begin{array}{c}\boldsymbol{N} \text { (3rd round in } \\
\text { February 2015) }\end{array}$ \\
\hline Participants of the TDTs & 14 & 9 & 8 \\
Coaches & 6 & 5 & 6 \\
$\begin{array}{l}\text { Coordinators of the teacher } \\
\text { education program }\end{array}$ & 4 & 6 & 3 \\
Researchers & 8 & 6 & 10 \\
\hline Total participants & $\mathbf{3 2}$ & $\mathbf{2 6}$ & $\mathbf{2 7}$ \\
\hline
\end{tabular}

\section{Conduct of the Delphi study and analysis of the results}

As mentioned before, the Delphi study consisted of three rounds of data collection and analysis. For each round, instruments were developed and pilot-tested by five to ten fellow researchers and teacher educators. In this section, we describe the development and implementation of each instrument per round. The Delphi study started with a literature review that served as foundation for the first questionnaire. Data from the first open-ended questionnaire was analysed in order to develop the second-round survey. The results of 
the second round served as the basis for the next one. The results of the third and last round are described extensively as the final results of this study.

\section{First round}

Design of the questionnaire based on the literature review

As the starting point of the Delphi study, nine themes concerned with conditions for the implementation of TDTs (e.g., the role of the coach) were derived from a literature review of key studies about the implementation and working of TDTs (see Table 1). An open-ended questionnaire was developed based on these themes to ascertain whether and why each theme was perceived as important for the implementation of TeDTs for the use of educational technology. For the first round we deliberately chose an open-ended questionnaire so that respondents could have a greater role in setting the agenda than is possible with conventional surveys (Hasson, Keeney, \& McKenna, 2008; Mullen, 2003). The survey started with a general question, "Which conditions are important for the successful implementation of TeDTs for ICT integration?”, to capture participants' broad perspectives about this topic before zooming into the specific themes emerging from the literature.

\section{Results of the first round: emerging conditions}

Based on the data from 32 respondents, various conditions for each of the nine themes derived from the literature review were identified through inductive analysis of the survey data. Participant responses were coded iteratively by the members of the research team with the help of a qualitative data analysis software (NVivo 10). The first author coded the data, identifying emerging conditions regarded as important across various stakeholder groups. The coding was then discussed and refined with the entire research team, resulting in the identification of 76 conditions: nine about the design task, nine about team composition, six about collaboration, seven about design activities, 11 about the role of the coach, six about external support, 11 about the role of the institution, 11 about coordination procedures and six about structural conditions.

\section{Second round}

Identification of important conditions in the second round

With the aim of reaching consensus about which conditions are regarded as most important, the 76 conditions resulting from the first round were brought together in a quantitative survey in the second round. The respondents were asked to score each condition on a six-point Likert scale from not important at all to necessary. They could add additional comments if desired.

Consensus in Delphi studies is defined in a variety of ways (Powell, 2002). In this study, the median and interquartile range (IQR) were used to identify conditions regarded as important by multiple stakeholders and to determine the level of consensus for each condition. The median denotes the middle point of a frequency distribution with half the scores falling above and half the scores falling below it (Doughty, 2009). A median $\geq 5$ (very important or necessary) was used as the basic criterion to take a condition to the next round. After the second round, 28 conditions with a median $\geq 5$ were retained because at least half of the respondents agreed that they are very important for the implementation of TeDTs for ICT integration.

The median is an appropriate measure to determine consensus with small groups, but the IQR is also often used to determine the degree of consensus in a Delphi study (Doughty, 2009). The IQR represents the middle half of responses within a distribution of scores, whereby a small IQR indicates a higher level of consensus and a large IQR indicates a lower level of consensus (Doughty, 2009). For each condition with a median $\geq 5$ we calculated the IQR and we differentiated among three levels of variation in responses. A high level of consensus is reached when there is an IQR $\leq 0.5$, which indicates that half of the opinions fall within 0.5 point around the median (Von der Gracht, 2012). We talk about a moderate level of consensus when the IQR is higher than 0.5 but smaller or equal to 1 . This IQR shows that half of the opinions are placed within 0.5 to 1 point around the median. Lower level of consensus is reached with an IQR $>1$, because more than $50 \%$ of all opinions fall without 1 point around the median (Von der Gracht, 2012).

Results of the second round

Table 3 gives an overview of the 28 conditions with median 5 or 6 resulting from the second round. After this round, four out of nine conditions were left within the theme design task, five out of nine regarding team composition, two out of six regarding collaboration, three out of seven within the theme design activities and three out of eleven pertaining to the role of the coach. At the institutional level, eight out of 
eleven conditions were left within the theme the role of the institution and three out of six about structural conditions. Notably, no conditions were left within the themes external support and coordination procedures, suggesting that there is no consensus regarding the importance of conditions related to these themes for the successful implementation of TeDTs for ICT integration. Looking at IQR as the measure for indicating the degree of consensus, there are no conditions with high consensus. There is, however, moderate consensus for 18 conditions and low consensus regarding the importance of 10 conditions.

Table 3

28 conditions with median $\geq 5$ after the second round

\begin{tabular}{|c|c|c|}
\hline Themes & Conditions & $\begin{array}{l}\text { Degree of } \\
\text { consensus* }\end{array}$ \\
\hline \multirow[t]{4}{*}{ Design task } & 1. The design task leads to a solution for a problem participants have. & Moderate \\
\hline & $\begin{array}{l}\text { 2. The design task encourages participants to act in a research- } \\
\text { oriented manner. }\end{array}$ & Moderate \\
\hline & 3. The solution of the design task can be used over the long term. & Moderate \\
\hline & $\begin{array}{l}\text { 4. The design task consists of technological, pedagogical and content } \\
\text { components. }\end{array}$ & Low \\
\hline \multirow[t]{5}{*}{$\begin{array}{l}\text { Team } \\
\text { composition }\end{array}$} & $\begin{array}{l}\text { 5. The TeDT is composed of a heterogeneous group with teacher } \\
\text { educators with different expertise, so they can complement each } \\
\text { other. }\end{array}$ & Moderate \\
\hline & 6. Each teacher educator is intrinsically motivated to participate. & Moderate \\
\hline & 7. All participants are open to innovation. & Low \\
\hline & $\begin{array}{l}\text { 8. All participants trust each other's expertise and trust each other as } \\
\text { colleagues. }\end{array}$ & Low \\
\hline & 9. All participants are open to giving and to receiving feedback. & Moderate \\
\hline \multirow[t]{2}{*}{ Collaboration } & $\begin{array}{l}\text { 10. All participants feel a responsibility towards the design task and the } \\
\text { results. }\end{array}$ & Moderate \\
\hline & 11. The collaboration is aimed at getting results. & Moderate \\
\hline \multirow[t]{3}{*}{$\begin{array}{l}\text { Design } \\
\text { activities }\end{array}$} & $\begin{array}{l}\text { 12. The design process starts with a thorough analysis of the beginning } \\
\text { situation. }\end{array}$ & Low \\
\hline & 13. The designed product is tested in practice. & Low \\
\hline & $\begin{array}{l}\text { 14. The designed product is evaluated and reworked after being tested } \\
\text { in practice. }\end{array}$ & Low \\
\hline \multirow[t]{3}{*}{$\begin{array}{l}\text { The role of } \\
\text { the coach }\end{array}$} & $\begin{array}{l}\text { 15. The coach drives and guides the design process, so that participants } \\
\text { continue to think and design. }\end{array}$ & Moderate \\
\hline & $\begin{array}{l}\text { 16. The coach monitors the overview by, for example, providing a } \\
\text { roadmap and keeping the goal in mind. }\end{array}$ & Moderate \\
\hline & 17. The coach is flexible and adapts to the needs of the participants. & Low \\
\hline \multirow[t]{8}{*}{$\begin{array}{l}\text { The role of } \\
\text { the } \\
\text { institution }\end{array}$} & $\begin{array}{l}\text { 18. The institution provides the participants with a short but thorough } \\
\text { introduction to the concept of TeDTs, so that participants can get } \\
\text { off to a good start. }\end{array}$ & Moderate \\
\hline & $\begin{array}{l}\text { 19. TeDTs are implemented to stimulate professional development of } \\
\text { participants. }\end{array}$ & Moderate \\
\hline & 20. TeDTs are implemented to develop a quality product. & Moderate \\
\hline & $\begin{array}{l}\text { 21. The institution's policies are open to and supportive of the concept } \\
\text { of TeDTs. }\end{array}$ & Low \\
\hline & $\begin{array}{l}\text { 22. The institution's policies are supportive of innovations like ICT } \\
\text { integration. }\end{array}$ & Moderate \\
\hline & 23. The institution's policies provide support to the TeDT's coach. & Low \\
\hline & $\begin{array}{l}\text { 24. The institution's policies provide an administrative and } \\
\text { organisational framework for the concept of TeDTs. }\end{array}$ & Moderate \\
\hline & $\begin{array}{l}\text { 25. All participants are provided the opportunity to implement their } \\
\text { design in the institution. }\end{array}$ & Moderate \\
\hline \multirow[t]{3}{*}{$\begin{array}{l}\text { Structural } \\
\text { conditions }\end{array}$} & $\begin{array}{l}\text { 26. Each TeDT has access to a user-friendly digital learning } \\
\text { environment. }\end{array}$ & Low \\
\hline & 27. Teacher educators are given the time to participate. & Moderate \\
\hline & 28. The coach is given the time to participate. & Moderate \\
\hline
\end{tabular}




\section{Third round}

Consensus confirmation in the third round

In order to give respondents the opportunity to revise their answers, the 28 conditions resulting from the second round were used in the survey for the final round. In this round, respondents were provided with information about the degree of consensus in the previous round. Respondents were asked to score these 28 conditions again on the same 6-point Likert scale from not important at all to necessary. This provided respondents with the opportunity to rescore conditions. After this last round, we also calculated medians and IQR, using the same criteria as that of the data analysis of the second round.

\section{Results of the third round}

At least half of the respondents agreed about the importance of ten conditions (median $\geq 5$ ) for the implementation of TeDTs for ICT integration after the third round (see Table 4). In this round, no conditions with a median $\geq 5$ were identified for the theme design activities. Only ten conditions within six themes were left at the end of this study: two (out of four compared with the second round) conditions regarding the design task, three (out of five) regarding team composition, one (out of two) within the theme collaboration and one (out of three) within the role of the coach. From these seven conditions at the team level, there is moderate consensus (based on IQR) on 5 of them pertaining to the design task $(n=1)$, team composition $(n=3)$ and collaboration $(n=1)$. Interestingly, there was more consensus in the third round (a shift from low to moderate) about the need for "participants who are open to innovation and who trust each other's expertise and trust each other as colleagues" than there was in the previous round.

Table 4

Ten conditions on which there is consensus about their importance after the third round

\begin{tabular}{|c|c|c|}
\hline Themes & Conditions & $\begin{array}{l}\text { Level of } \\
\text { consensus* }\end{array}$ \\
\hline \multirow[t]{2}{*}{ Design task } & $\begin{array}{l}\text { 29. The solution of the design task can be used over the long } \\
\text { term. }\end{array}$ & Moderate \\
\hline & $\begin{array}{l}\text { 30. The design task consists of technological, pedagogical and } \\
\text { content components. }\end{array}$ & Low \\
\hline \multirow[t]{3}{*}{ Team composition } & 31. All participants are open to innovation. & Moderate \\
\hline & $\begin{array}{l}\text { 32. All participants trust each other's expertise and trust each } \\
\text { other as colleagues. }\end{array}$ & Moderate \\
\hline & 33. All participants are open to giving and receiving feedback. & Moderate \\
\hline Collaboration & $\begin{array}{l}\text { 34. All participants feel a responsibility towards the design task } \\
\text { and the results. }\end{array}$ & Moderate \\
\hline Role of the coach & $\begin{array}{l}\text { 35. The coach is flexible and adapts to the needs of the } \\
\text { participants. }\end{array}$ & Low \\
\hline $\begin{array}{l}\text { Role of the } \\
\text { institution }\end{array}$ & $\begin{array}{l}\text { 36. The institution's policies are open to and supportive of the } \\
\text { concept of TeDTs. }\end{array}$ & Low \\
\hline \multirow[t]{2}{*}{ Structural conditions } & 37. Teacher educators are given the time to participate. & Low \\
\hline & 38. The coach is given the time to participate. & Low \\
\hline
\end{tabular}

At the institutional level, there was consensus over the importance of three conditions: 1 (out of 8 compared with the second round) regarding the role of the institution and 2 (out of 3) regarding structural conditions. However, the degree of consensus, based on IQR, is low for all of them, meaning that more than half of the opinions fall 1 point apart from the median. Between the second and third round, there was a shift in the degree of consensus (from moderate to low) for both structural conditions pertaining to time. After the third round, there seems to be less convergence about how important these two conditions are.

\section{Discussion}

To the best of our knowledge, this is the first study that focuses explicitly on consensus across multiple stakeholders about important conditions for the implementation of TDTs. Previous research identifies various conditions that play a role, but mostly from the perspective of one stakeholder group. In this study, the viewpoint of multiple stakeholder groups was brought together to establish consensus about crucial conditions for the implementation of TeDTs for ICT integration. Although the implementation of TDT in 
teacher education was the focus of this study, results can also be applicable to other domains of higher education. One argument is that profiles of the stakeholders of this study were broader than teacher education. The current Delphi study identified ten conditions regarded as very important by at least half of the stakeholder groups. Figure 1 gives an overview of these conditions. Each condition is discussed below and illustrated by qualitative data from the first and second rounds of the Delphi study. Subsequently, we discuss the limitations of this study and make recommendations for further research.

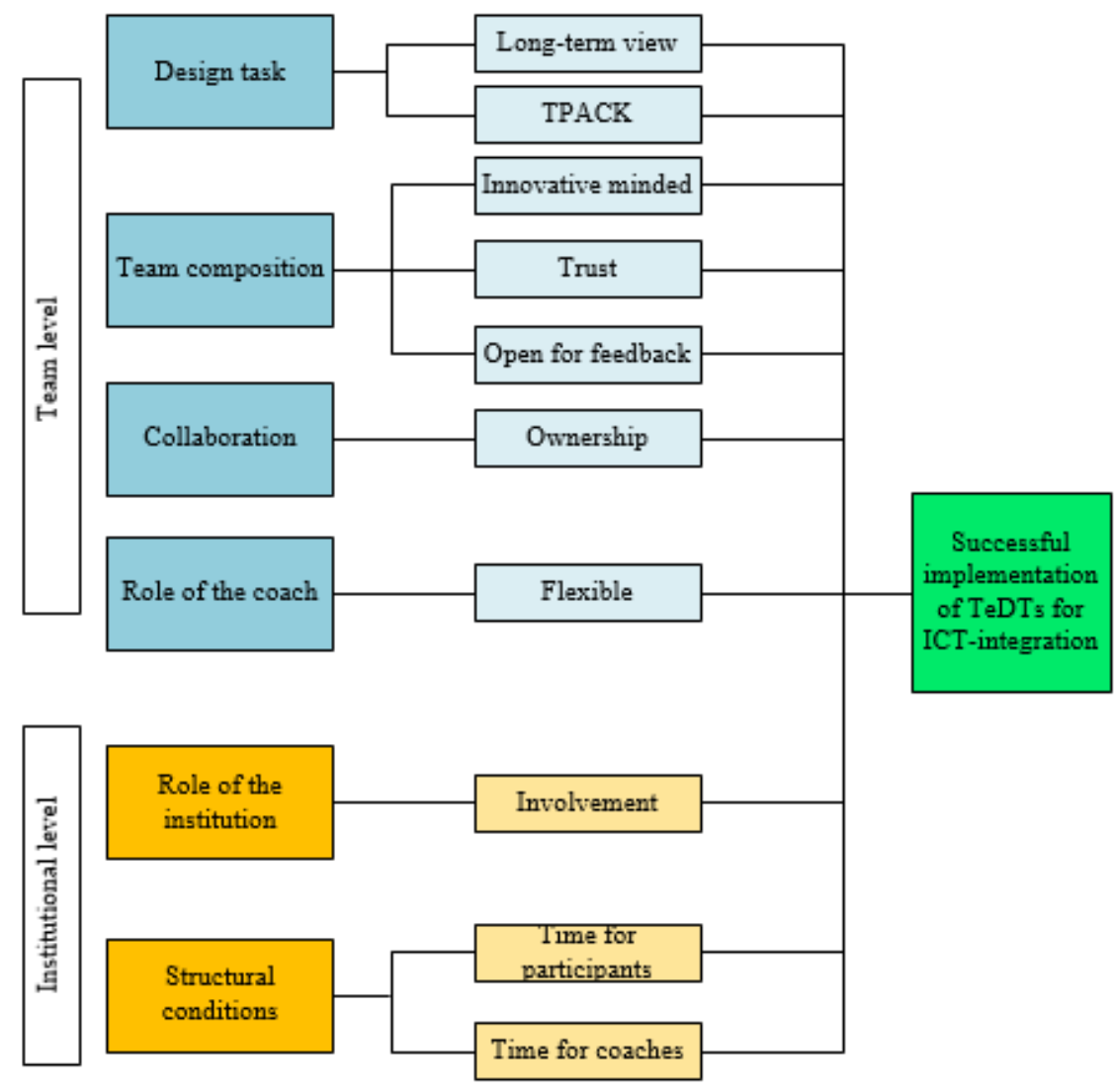

Figure 1. Conditions important for the successful implementation of TeDTs for ICT integration

\section{Important conditions at the team level}

Our findings reveal the importance of a long-term perspective in the design task. As stated by a teacher educator, "The design task must have an added value on different levels: directly on the short term and indirectly over the long term”. This long-term view seems relevant to help teachers make connections between the professional development experiences and their daily work (Whitcomb, Borko, \& Liston, 2009), thereby increasing the perceived practicality of it (Janssen, Westbroek, Doyle, \& Van Driel, 2013). In this respect, Binkhorst et al. (2015) found some teachers perceived that participating in a TDT saves time in the long term because the designed material can be used year after year. Beyond the long-term perspective, the type, specific features and scope of the design task have also been identified as important (cf. Frankenberger \& Auer, 1997). However, it remains unclear which concrete criteria a design task must meet. The case of ICT integration possibly determines some criteria but contexts plays an important role as well. In Flanders, ICT integration is not a separate subject in most teacher education programs, but an interdisciplinary goal that must be pursued. Therefore, most TeDTs in this project chose the development of curriculum materials for ICT integration that could be used in different years and/or subject domains. Moreover, the respondents in this study emphasised that the design task should not consist only of a technological component and that pedagogical and content completion are equally important. A teacher educator commented, "ICT should be the means to an end, in which case you should first think about what you want to achieve and with which contents, in order to then focus on the potential added value of integrating ICT”. Mishra and Koehler (2006) also stress that ICT integration in teacher education is facilitated when teacher educators understand how knowledge of technology, pedagogical knowledge and content knowledge are interrelated and how they interact with each other. 
Attitudes that teacher educators show towards ICT are a crucial factor when designing technologyenhanced curriculum materials (e.g., Mirzajani, Mahmud, Ayub, \& Luan, 2015). Many teacher educators still have an initial resistance to integrating ICT in their practices (e.g., Mirzajani et al., 2015). Collaboratively designing curriculum materials for ICT integration therefore needs to be well considered to overcome this resistance (McKenney et al., 2015). Results of the third round revealed consensus about the importance of participants who are open-minded about innovation, who trust each other as colleagues and who have confidence in each other's expertise. To illustrate: when asked "What would you take into account when composing a TeDT for ICT integration?”, one coach stated:

Listening to each other, talking and discussing freely with each other (without leaving someone hurt or insulted), taking feedback from others seriously, daring to remain quiet, daring to bring up own ideas and daring to say when you need help.

Hence, giving and receiving feedback must be (made) possible in the group. In line with Cober et al. (2015), we conclude that the creation of an atmosphere of trust is very important in the collaboration process of designing curriculum materials for ICT integration.

Another condition emphasised as important by the respondents in this study is the feeling of ownership over the design process. All participants need to feel responsible for the design task. Previous research also indicates the importance of a shared feeling of responsibility (e.g., Stoll et al., 2006). If team members do not feel largely responsible for the outcomes, they may need additional support (Handelzalts, 2009). Such support can be provided by a coach. We asked the respondents "To what extent and in what ways can a coach offer support to a TeDT for ICT integration?". They stated that a coach must "provide support the moment participants ask for it” (coach), "give just-in-time information and training” (researcher), "switch between taking distance and participating” (teacher educator) and so on. Flexibility seems to be the most important characteristic of a coach as also indicated by previous research (e.g., Huizinga et al., 2013; Petrone and Orquist-Ahrens, 2004).

\section{Important conditions at the institutional level}

At least half of the respondents agree about the importance of involved policy-makers. One of the coaches stated:

If the institution's policy is not behind the concept of TeDTs and if policymakers don't support the process in the institution, I think the implementation of TeDTs for ICT integration is much more difficult. If, however, a professionalisation culture open to collaboration between teachers to integrate ICT is present, it will facilitate its implementation.

The words of this coach resonate with those of other respondents and with findings from previous research which stress that active involvement of school leaders is required for an effective implementation of TDTs (e.g., Handelzalts, 2009; Voogt et al., 2011). Interestingly, there seems to be consensus over the importance of more conditions related to the role of the institution within the program coordinators group. Leaders clearly acknowledge their crucial role, feeling responsible for supporting TeDT coaches. They find it important to be open to innovation, to provide participants of a TeDT with a powerful introduction about the concept of TeDTs, and to implement TeDTs with the aim of professionalising teacher educators. Finally, they stated that it is important for TeDTs to have the opportunity to implement their designs in the institution, something for which there was also consensus amongst the researchers' stakeholder group.

Two final conditions resulting from this study are concerned with time as a structural condition. According to the coach of one of the TeDT, "For innovative design, people need time. If designing happens through other activities, it won't be innovative design.” The words of this coach show that both participants and the coach need time to participate in a TeDT. Too little time is seen as an obstruction, as is confirmed by other studies (e.g., Handelzalts, 2009; Stoll et al., 2006). Handelzalts (2009) claims that enough time needs to be combined with enough support. This leads us to previous conditions whereby the coach and the institution have an important supporting role for the effective implementation of TeDT for ICT integration.

\section{Limitations of the study and directions for future research and practice}


This study used the Delphi method. Though time-consuming because of the iterative data collection, a Delphi study is a good method to reach consensus (Shaikh \& Khoja, 2014) in a broad group of experts (Koster, 2003). Looking at a range of conditions for the implementation of TeDTs for ICT integration from different views allowed us to identify those conditions regarded as crucial by all stakeholders. Nevertheless, for a number of conditions, consensus was reached within a particular stakeholder group. But not across groups. For example, at least half of the researchers agree that a practical problem must be the starting point to define a design task. Another example is the emphasis participants of TeDTs place on the importance of being intrinsically motivated to take part in a TeDT. Only coaches focus on the importance of design activities, such as a thorough analysis of the design problem, pilot testing and evaluation. Further research is warranted to determine the priorities within single respondent groups and to examine the different priorities between respondent groups. What makes some conditions so controversial? Another limitation of the current study is that consensus was restricted to a specific part of the range (cf. Diamond et al., 2014) as we looked only at consensus about conditions regarded as very important. We did not look at those conditions found not important across multiple stakeholder groups in detail. Investigating what is not important can provide insight into those conditions TeDTs should not waste time and energy on. After the second round, for example, at least half of the stakeholders agreed that it is not important that TeDTs are composed of teacher educators from the same institution.

How to define consensus in a Delphi study is not an easy task, considering that consensus can be determined in a variety of ways (Doughty, 2009). In this study the median and IQR were calculated, since these measures are often used to determine consensus. Because we were interested in conditions considered important, consensus about the importance of a condition was identified when at least half of the respondents scored the condition as very important (median $\geq 5$ ). Looking at IQR as a second measure to define the level of consensus, we didn't identify conditions with high consensus (IQR $\leq 0.5)$. Since there are no fixed sizes to determine consensus, another choice (e.g., IQR $\leq 1$ means high consensus) made by the researchers could have yielded different outcomes (e.g., more conditions with a high level of consensus). A critical view of the results is therefore essential.

A last issue that requires further investigation is the specificity of the conditions. We included only respondents involved in one particular TDT project, consisting of four separate TeDTs. Are the outcomes of this study consequently case-specific? Are the conditions specifically related to the composition of a team (student teachers, teachers or teacher educators) or to the design focus (e.g., ICT integration)? Future research might ascertain whether in different contexts and cases the same or other conditions are regarded as important.

\section{Conclusion}

This Delphi study was set up to identify conditions perceived to be important for the successful implementation of TeDTs for ICT integration from the perspective of multiple stakeholders. After three rounds of data collection there was consensus about the importance of ten conditions. Conditions at the level of the team pertained to team composition $(n=3)$, the design task $(n=2)$, collaboration $(n=1)$ and the role of the coach $(n=1)$. At the level of the institution, leadership involvement and time (for participants and coaches) were identified as crucial. The outcomes can support teacher education institutions who wish to implement TeDTs for ICT integration. Although this study was case-specific, the results can inform TDTs in other contexts since the importance of the identified conditions has also been confirmed by previous research. We can tentatively conclude that creating an atmosphere of trust, responsible participants with a shared TPACK goal over the long term, an involved institutional leadership which provides time for all those participating, and just-in-time and hands-on support by a flexible coach are all important conditions for the effective implementation of TeDT.

\section{References}

Aesaert, K., Vanderlinde, R., Tondeur, J., \& van Braak, J. (2013). The content of educational technology curricula: a cross-curricular state of the art. Educational Technology Research and Development, 61(1), 131-151. doi:10.1007/s11423-012-9279-9

Agyei, D. D. (2012). Preparation of pre-service teachers in Ghana to integrate information and communication technology in teaching mathematics [Doctoraatsproefschrift]. Universiteit van Twente, Enschede. Retrieved from http://doc.utwente.nl/80660/ 
Agyei, D. D., \& Voogt, J. (2012). Developing technological pedagogical content knowledge in preservice mathematics teachers through collaborative design. Australasian Journal of Educational Technology, 28 (4), 547-564. doi:10.14742/ajet.827

Alayyar, G. M., Fisser, P., \& Voogt, J. (2012). Developing technological pedagogical content knowledge in pre-service science teachers: support from blended learning. Australasian Journal of Educational Technology, 28 (8), 1298-1316. doi:10.14742/ajet.773

Angeli, C., \& Valanides, N. (2009). Epistemological and methodological issues for the conceptualization, development, and assessment of ICT-TPCK: Advances in technological pedagogical content knowledge (TPCK). Computers \& Education, 52(1), 154-168. doi:10.1016/j.compedu.2008.07.006

Banas, J. R., \& York, C. S. (2014). Authentic learning exercises as a means to influence preservice teachers' technology integration self-efficacy and intentions to integrate technology. Australasian Journal of Educational Technology, 30(6). doi:10.14742/ajet.362

Becuwe, H., Tondeur, J., Pareja Roblin, N., Thys, J., \& Castelein, E. (2016). Teacher design teams as a strategy for professional development: The role of the facilitator. Educational Research and Evaluation, 1-14. doi:10.1080/13803611.2016.1247724

Binkhorst, F., Handelzalts, A., Poortman, C., \& van Joolingen, W. (2015). Understanding teacher design teams - A mixed methods approach to developing a descriptive framework. Teaching and Teacher Education, 51, 213-224. doi:10.1016/j.tate.2015.07.006

Cober, R., Tan, E., Slotta, J., So, H-J., \& Könings, K. D. (2015). Teachers as participatory designers: two case studies with technology-enhanced learning environments. Instructional Science, 43(2), 203-228. doi:10.1007/s11251-014-9339-0

Culatta, R. (2013). Instructional design models. In Instructional design. Retrieved from http://www.instructionaldesign.org/models/

Diamond, I. R., Grant, R. C., Feldman, B. M., Pencharz, P. B., Ling, S. C., Moore, A. D., \& Wales, P. W. (2014). Defining consensus: A systematic review recommends methodologic criteria for reporting of Delphi studies. Journal of Clinical Epidemiology, 67(4), 401-409. doi:10.1016/j.jclinepi.2013.12.002

Doughty, E.A. (2009). Investigating adaptive grieving styles: a Delphi study. Death Studies, 33(5), 462480. doi:10.1080/07481180902805715

Ehrlenspiel, K., Giapoulis, A., \& Günther, J. (1997). Teamwork and design methodology: Observations about teamwork in design education. Research in Engineering Design, 9(2), 61-69. doi:10.1007/BF01596482

Frankenberger, E., \& Auer, P. (1997). Standardized observation of team-work in design. Research in Engineering Design, 9(1), 1-9. doi:10.1007/BF01607053

Goktas, Y., Yildirim, S., \& Yildirim, Z. (2009). Main barriers and possible enablers of ICTs integration into pre-service teacher education programs. Educational Technology and Society, 12(1), 193-204. Retrieved from http://www.ifets.info/journals/12_1/15.pdf

Handelzalts, A. (2009). Collaborative curriculum development in teacher design teams (Doctoral thesis). University of Twente, Enschede. Retrieved from http://doc.utwente.nl/67385/1/thesis_A_Handelzalts.pdf

Hargreaves, A. (2011). Push, pull and nudge: The future of teaching and educational change. In X. Zhu \& K. Zeichner (Eds.), Preparing teachers for the 21st century (pp. 217-236). Berlin: Springer.

Hasson, F., Keeney, S., \& McKenna, H. (2000). Research guidelines for the Delphi survey technique. Journal of Advanced Nursing, 32, 1008-1015. doi:10.1046/j.1365-2648.2000.t01-1-01567.x

Hipp, K. K., Huffman, J. B., Pankake, A. M., \& Olivier, D. F. (2008). Sustaining professional learning communities: Case studies. Journal of Educational Change, 9(2), 173-195. doi:10.1007/s10833-0079060-8

Hord, S. M. (1997). Professional learning communities: Communities of continuous inquiry and improvement. Austin, TX: Southwest Educational Development Laboratory.

Hsu, C.-C., \& Sandford, B. A. (2007). The Delphi technique: Making sense of consensus. Practical Assessment, Research and Evaluation, 12(10), 1-8. Retrieved from http://pareonline.net/pdf/v12n10.pdf

Huizinga, T., Handelzalts, A., Nieveen, N., \& Voogt, J. (2013). Teacher involvement in curriculum design: Need for support to enhance teachers' design expertise. Journal of Curriculum Studies, 46(1), 33-57. doi:10.1080/00220272.2013.834077

Janssen, F., Westbroek, H., Doyle, W., \& Van Driel, J. H. (2013). How to make innovations practical. Teachers College Record, 115, 1-42. Retrieved from http://www.tcrecord.org/library/abstract.asp?contentid=17052 
Jenlink, P. M. \& Kinnucan-Welsch, K. (2001). Case stories of facilitating professional development. Teaching and Teacher Education, 17(6), 705-724. doi:10.1016/S0742-051X(01)00025-7

Kay, R. H. (2006). Evaluating strategies used to incorporate technology into preservice education: A review of the literature. Journal of Research on Technology in Education, 38(4), 383-408. doi:10.1177/0888406409346144

Knight, S. L, Lloyd, G. M., Arbaugh, F., Gamson, D., McDonald, S. P., \& Nolan, J. (2014). Professional development and practices of teacher educators. Journal of Teacher Education, 65(4), 268-270. doi:10.1177/0022487114542220

Koster, B. (2003). Lerarenopleiders stellen eisen aan zichzelf. VELON tijdschrift voor lerarenopleiders, 24 (2), 23-32. Retrieved from http://www.lerarenopleider.nl/velon/blog/tijdschrift/j2003/lerarenopleiders-stellen-eisen-aan-zichzelf/

Lee, Y., \& Lee, J. (2014). Enhancing pre-service teachers' self-efficacy beliefs for technology integration through lesson planning practice. Computers \& Education, 73, 121-128. doi:10.1016/j.compedu.2014.01.001

Little, L. W. (1990). The persistence of privacy: autonomy and initiative in teachers' professional relations. Teachers College Record, 91(4), 509-536. Retrieved from http://www.tcrecord.org/library/abstract.asp?contentid=406

McKenney, S., Kali, Y., Markauskaite, L., \& Voogt, J. (2015). Teacher design knowledge for technology enhanced learning: an ecological framework for investigating assets and needs. Instructional Science, 43(2), 181-202. doi:10.1007/s11251-014-9337-2

McLaughlin, M. W., \& Talbert, J. E. (2001). Professional communities and the work of high school teaching. Chicago, IL: University of Chicago Press.

Mirzajani, H., Mahmud, R., Ayub, A. F. M., \& Luan, W. S. (2015). A review of research literature on obstacles that prevent use of ICT in pre-service teachers' educational courses. International Journal of Education and Literacy Studies, 3(2), 25-31. doi:10.7575/aiac.ijels.v.3n.2p.25

Mishra, P., \& Koehler, M. J. (2006). Technological pedagogical content knowledge: A framework for teacher knowledge. Teachers College Record, 108(6), 1017-1054. doi:10.1111/j.14679620.2006.00684.x

Mullen, P.M. (2003). Delphi study: Myths and reality. Journal of Health Organization and Management, 17(1), 37-52. doi:10.1108/14777260310469319

Niess, M. L., Ronau, R. N., Shafer, K. G., Driskell, S. O., Harper S. R., Johnston, C., Browning, C., Özgün-Koca, S. A., \& Kersaint, G. (2009). Mathematics teacher TPACK standards and development model. Contemporary Issues in Technology and Teacher Education, 9(1), 4-24. Retrieved from http://www.citejournal.org/vol9/iss1/mathematics/article1.cfm

Okoli, C., \& Pawlowksi, S. D. (2004). The Delphi method as a research tool: An example, design considerations and applications. Information and management, 42(1), 15-29. doi:10.1016/j.im.2003.11.002

Paulus, P. B. (2000). Groups, teams and creativity: The creative potential of idea-generating groups. Applied Psychology: An International Review, 49(2), 237-262. doi:10.1111/1464-0597.00013

Peeraer, J., \& Van Petegem, P. (2012). The limits of programmed professional development on integration of information and communication technology in education. Australasian Journal of Educational Technology, 28(Special issue, 6), 1039-1056. doi:10.14742/ajet.809

Petrone, M. C., \& Ortquist-Ahrens, L. (2004). Facilitating faculty learning communities: a compact guide to creating change and inspiring community. New Directions for Teaching and Learning, 97, 63-69. doi:10.1002/tl.133

Polly, D. (2011). Teachers' learning while constructing technology-based instructional resources. British Journal of Educational Technology, 42(6), 950-961. doi:10.1111/j.1467-8535.2010.01161.X

Powell, C. (2002). The Delphi technique: Myths and realities. Journal of Advanced Nursing, 41, 376382. doi:10.1046/j.1365-2648.2003.02537.x

Shaikh, Z. A., \& Khoja, S. A. (2014). Personal learning environments and university teacher roles explored using Delphi. Australasian Journal of Educational Technology, 30(2), 202-226. doi:10.14742/ajet.324

Somech, A., \& Drach-Zavary, A. (2007). Schools as team-based organizations: A structure-processoutcomes approach. Groups Dynamics: Theory, Research and Practice, 11(4), 305-320. doi:10.1037/1089-2699.11.4.305

Stoll, L., Bolam, R., McMahon, A., Wallace, M., \& Thomas, S. (2006) Professional learning communities: A review of the literature. Journal of Educational Change, 7(4), 221-258. doi:10.1007/s10833-006-0001-8 
Svihla, V., Reeve, R., Sagy, O., \& Kali, Y. (2015). A fingerprint pattern of supports for teachers’ designing of technology-enhanced learning. Instructional Science, 43(2), 283-307. doi:10.1007/s11251-014-9342-5

Tack, H., \& Vanderlinde, R. (2014). Teacher educators’ professional development: towards a typology of teacher educators' researcherly disposition. British journal of educational studies, 62(3), 297-315. doi:10.1080/00071005.2014.957639

Tondeur, J., Pareja Roblin, N., \& Thys, J. (2012). Teacher design teams als strategie voor ICT-integratie in de lerarenopleiding [SlideShare]. Retrieved from http://www.slideshare.net/jtondeur

Tondeur, J., Pareja Roblin, N., van Braak, J., Fisser, P., \& Voogt, J. (2013). Technological pedagogical content knowledge in teacher education: In search of a new curriculum. Educational Studies, 39(2), 239243. doi:10.1080/03055698.2012.713548

Tondeur, J., van Braak, J., Sang, G., Voogt, J., Fisser, P., \& Ottenbreit-Leftwich, A. (2012). Preparing pre-service teachers to integrate technology in education: A synthesis of qualitative evidence. Computers \& Education, 9(1), 134-144. doi:10.1016/j.compedu.2011.10.009

Tondeur, J., van Braak, J., Siddiq, F., \& Scherer, R. (2016). Time for a new approach to prepare future teachers for educational technology use: Its meaning and measurement. Computers \& Education, 94, 134-150. doi:10.13140/RG.2.1.1197.3367

Von der Gracht, H. A. (2012). Consensus measurement in Delphi studies: Review and implications for future quality assurance. Technological Forecasting and Social Change, 79(8), 1525-1536. doi:10.1016/j.techfore.2012.04.013

Voogt, J., Fisser, P., Pareja Roblin, N., Tondeur, J., \& van Braak, J. (2013. Technological pedagogical content knowledge - a review of the literature. Journal of Computer Assisted Learning, 29(2), 109-121. doi:10.1111/j.1365-2729.2012.00487.x

Voogt, J., Laferrière, T., Breuleux, A., Itow, R. C., Hickey, D. T., \& McKenney, S. (2015). Collaborative design as a form of professional development. Instructional Science, 42(2), 259-282. doi:10.1007/s11251-014-9340-7

Voogt, J., Westbroek, H., Handelzalts, A., Walraven, A., McKenney, S., Pieters, J., \& de Vries, B. (2011). Teacher learning in collaborative curriculum design. Teaching and Teacher Education, 27(8), 1235-1244. doi:10.1016/j.tate.2011.07.003

Wentworth, N., Graham, C. R., \& Monroe, E. E. (2009). Linking stages of technological pedagogical content knowledge development through consistent evaluation criteria. In S. Ramanathan (Ed.), Handbook of research on new media literacy at the K-12 level. Hershey, PA: Information Science Reference.

Whitcomb, J., Borko, H., \& Liston, D. (2009). Growing talent: Promising professional development models and practices. Journal of Teacher Education, 60(3), 207-212. doi:10.1177/0022487109337280

Corresponding author: Heleen Becuwe, becuweheleen@gmail.com

Australasian Journal of Educational Technology (c) 2017.

Please cite as: Becuwe, H., Pareja Roblin, N., Tondeur, J., Thys, J., Castelein, E., \& Voogt, J. (2017). Conditions for the successful implementation of teacher educator design teams for ICT integration: A Delphi study. Australasian Journal of Educational Technology, 33(2), 159-172. https://doi.org/10.14742/ajet.2789 